\title{
Girişimcilik Motivasyonu: Uygulamalı Girişimcilik Eğitimi Katılımcıları Örneği
}

\author{
Beyhan AKSOY* Mustafa KOÇANCI** Mete Kaan NAMAL ${ }^{* * *}$
}

$\ddot{O} Z$

Girişimciliğin, yenilikçilik, iş yaratma veya ekonomik büyüme üzerindeki etkileri önemli olmakla birlikte, bireyler düzeyinde girişimci olma isteğinin nedenlerini ve ilişkili olguları açıklamak girişimcilik süreçlerini anlamak için önemli bir katkl sağlayabilir. Bu çalışmada girişimcilik süreçlerine dair daha ayrıntılı bir anlayış geliştirmek amacıyla girişimcilik motivasyonu konusu incelenmiştir. Motivasyonun bireyleri harekete geçirdiği temel varsayımından hareketle KOSGEB Uygulamalı Girişimcilik Eğitimlerine katılan 589 girişimci adayına yüz yüze anket uygulanmış ve girişimci adaylarının girişimcilik motivasyonları açıklanmıştır. Çalışmada girişimcilik motivasyonunun ekonomik, girişimsel, toplumsal, çalışma ve bireycilik boyutlarının gelir, cinsiyet, tecrübe, eğitim gibi seçilmiş bazı değişkenler bakımından ilişkilerine dair bulgular tartışılmış ve yorumlanmıştır. Araştırma bulgularına göre, sosyal ve çalışma boyutları açısından erkelerin kadınlardan daha fazla motivasyona sahip oldukları bulunmuştur. Girişimcilik tecrübesi olanlar, girişimcilik tecrübesi olmayanlara göre daha fazla bireysel motivasyona sahiptir. Gelir düzeyi daha yüksek olanlar sosyal anlamda daha fazla motive olmaktadirlar. Gelir seviyesi daha yüksek olan girişimci adayları, diğer gelir grupları ve gelir dışı gruplardan daha fazla bireysel motivasyona sahiptir. Daha düşük eğitim seviyesine sahip girişsimci adaylarının, hem girişimcilik hem de ekonomik motivasyon boyutlarında daha yüksek eğitim almış olanlardan daha fazla motive oldukları bulunmuştur.

Anahtar Kelimeler: Girişimcilik, Girişimcilik Motivasyonu, KOSGEB Uygulamalı Girişimcilik Ĕ̌gitimi.

JEL Sinıflaması: L26, D91, M13

\section{Entrepreneurial Motivation: The Example of Applied Entrepreneurship Training Participants}

\begin{abstract}
While the impact of entrepreneurship on innovation, job creation or economic growth is important, explaining the reasons for the desire to become an entrepreneur at the individual level and the associated facts may provide an important contribution to understand the processes of entrepreneurship. In this study, entrepreneurship motivation is examined in order to develop a more detailed understanding of entrepreneurship processes. Based on the basic assumption that motivation sets individuals into motion, 589 entrepreneur candidates participating in KOSGEB Applied Entrepreneurship Trainings were interviewed face-to-face and entrepreneurship motivation of entrepreneur candidates was explained. In the study, the findings on the relationship between economic, entrepreneurial, social, work and individualism dimensions of entrepreneurship motivation in terms of selected variables such as income, gender, experience and education were discussed and interpreted. According to the research findings, it is found that men have higher motivation than women in terms of social and work attitudes. Those who have experience in
\end{abstract}

\footnotetext{
*Doç. Dr. Akdeniz Üniversitesi, IİBF, ÇEEI Bölümü, beyhanaksoy@ akdeniz.edu.tr

** Dr. Öğr. Üyesi, Akdeniz Üniversitesi, ÏBF, ÇEEİ Bölümü, mkocanci@ akdeniz.edu.tr

*** Dr. Öğr. Üyesi, Akdeniz Üniversitesi, İ̈BF, ÇEEİ Bölümü, namal@akdeniz.edu.tr
} 
entrepreneurship have more individualistic motivation than those without entrepreneurship experience. Those whose income level is higher are more motivated in social motivation dimension. Entrepreneurial candidates who have higher income levels also have higher level of individualistic motivation than other income groups and non-income groups. Entrepreneur candidates with lower levels of education have been found to be more motivated than those who are highly educated in both entrepreneurial and economic motivation dimensions.

Key Words: Entrepreneurship, Entrepreneurial Motivation, KOSGEB Applied Entrepreneurship Training.

JEL Classification: L26, D91, M13

\section{GİRIŞ}

Yeni fikirlerin, buluşların ortaya çıkarılması ve hayata geçirilerek mal ve hizmetlere dönüştürülmesi ile toplumsal yaşamının daha nitelikli bir hale getirilmesi birbirleriyle doğrudan ilişkilidir. Başarılı girişimler, toplumsal refahın geliştirilmesine katkı sağladıkları ve bireylere iş firsatları yarattıkları için, girişimciliğe dair farkındalık oluşturulması, girişimciliğin yaygınlaştırılması ve bireylerin girişimcilik motivasyonlarının artırılması gibi çabaları hemen hemen tüm ülke ekonomilerinde gözlemlemek mümkündür.

Bir politika olarak ulusal düzeyde yenilikçilik, iş yaratma veya ekonomik büyüme elde etmek üzere girişimciliğe verilen öneme rağmen, bireyler düzeyinde girişimciliğe yönelmenin temelinde çoğunlukla bunlar yer almamaktadır. Bunun yerine bireyler, kişisel kazanç veya özerklik arzusu ile ya da başka bir seçeneğe sahip olmadıkları için girişimciliğe yönelirler (Hessels vd., 2008). Bu sebeple kişileri girişimciliğe yönelten motivasyonları anlamak ve açıklamak önemli bir konu haline gelmiştir.

Küresel Girişimcilik Monitörü (GEM), son 20 y1ldır belirli ölçütler çerçevesinde dünya ülkelerinin karşılaştırmalı girişimcilik raporlarını sunmaktadır. $\mathrm{Bu}$ inisiyatifin hazırladığı Küresel Girişimcilik Endeksi, girişimcilik seviyelerinin istikrarlı veya küresel olarak yükselişe geçtiğini ve firsat odaklı girişimciliğin baskın olduğunu bildirmektedir. Dünya nüfusunun \% 68'ini ve dünya GSYİH'nın \% 86'sını kapsayan 2017/18 GEM araştırmasına göre, küresel nüfusun \% 43'ü sonraki altı ay içinde bir işe başlamak için iyi firsatlar görmektedir. Girişimcilik firsatları, "yeni mallar, hizmetler, hammaddeler ve örgütlenme yöntemlerinin, üretim maliyetlerinden daha fazla bir fiyatla pazara sunulup satılabildiği durumlar" şeklinde tanımlanmaktadır (Shane ve Venkataraman, 2000). GEM'in adı geçen raporuna göre araştırma katılımcılarının \% 74'ü girişimci motivasyonlarının temelini bir firsat peşinde koşma olarak tanımlamaktadır. En düşük fırsat motivasyonu en az gelişmiş ülkelerin olduğu faktör güdümlü ekonomilerde (\% 67,6) görülmektedir. Avrupa için bu oran \% 75,4; Asya ve Okyanusya için \% 74,4; Kuzey Amerika için ise \% 82,6'dır (GEM, 2018).

Ülkemizde girişimcilik kültürünü yaygınlaştırmak, girişimciliği geliştirmek ve girişimlerin sürdürülebilirliğini sağlamak " amaciyla KOSGEB 2010 yılından bu yana girişimcilik eğitimleri düzenlemektedir. Son üç yıl içinde (2016, 2017 ve 2018) 1.900'ü doğrudan KOSGEB ve 18.548'i KOSGEB ile diğer kurum/kuruluşlar arasında yapılan iş birlikleri ile gerçekleştirilen Uygulamalı Girişimcilik Eğitimi sayısı toplamda 20.448 'dir. Destek programında ve 
uygulamalı girişimcilik eğitimlerinde gözlemlenen bazı sorunlara rağmen (Namal vd., 2018) her yıl çok sayıda girişimci adayı bu eğitim programlarına katılarak sertifika almaktadır. 2016-2018 yılları arasında Uygulamalı Girişimcilik Eğitimi programlarını tamamlayarak sertifika alan girişimci adayı sayısı 539.753'tür. Yeni Girişimci Desteğinden yararlanan işletme sayısı ise anılan yıllar için 46.685 olarak gerçekleşmiştir (KOSGEB, 2018).

Küresel anlamda firsat girişimciliğinin \% 74 gibi (GEM, 2018) büyük oranla daha baskın olduğu görülse de, küçük ve orta ölçekli girişimlerde, özellikle devletin sunduğu teşviklerle bir iş kurmayı hedefleyen kesimler için, durum bundan daha farklı biçimlerde ortaya çıabilmektedir. Nispeten küçük bir sermaye ile bir iş kurmaya yönelen bu kesimlerin girişimcilik motivasyonlarını açıklamak, kamu kaynaklarından aktarılan işgücü, zaman ve finansmanın büyüklüğü göz önünde bulundurulduğunda daha önemli hale gelmektedir.

Bu sebeplerle bu çalışma ile KOSGEB girişimcilik eğitimlerine katılarak bir iş kurma niyeti olan girişimci adaylarının girişimcilik motivasyonlarını açıklamak üzere yapmış olduğumuz alan araştırmasından elde ettiğimiz verilere dayanarak konuya dair anlayışı geliştirmeyi ve bazı öneriler sunmayı amaçlamaktayız.

\section{GÍRIŞSIMCILIIK SÜREÇLERINE SOSYO-EKONOMIK VE PSİKOLOJIK YAKLAŞIMLAR}

Girişimcilik, daha önce bulunmayan yeni mal ve hizmetleri, pazarları, süreçleri, örgütlenme yollarını ve hammaddeleri sunma fırsatlarını keşfetmeyi, değerlendirmeyi ve kullanmayı içermektedir (Venkataraman, 1997; Shane ve Venkataraman, 2000). Girişimcilik süreçlerine ekonomik yaklaşımların çoğu, girişimcilik motivasyonunun bir iş kurma ve ücretli çalışma arasında beklenen faydadaki farklılığa dayandığını göstermektedir (Vangelderen vd., 2005). Bireyin girişimci veya ücretli çalışan olarak herhangi bir meslekten elde ettiği faydası, karar alma kontrolü, riske maruz kalma, gereken iş çabası ve çalışma koşulları olduğu kadar, elde ettiği gelire de bağlıdır. Tüm bunların toplamı ve elde edilen düzey belirli bir işte çalışma konusundaki isteği ya da isteksizliği belirlemektedir (Douglas ve Shepherd, 1999).

Girişimcilik literatüründeki ekonomik yaklaşımların yanı sıra farklı yazarların girişimcinin psikolojik özellikleri konusundaki bakış açılarından bazılarını, özerklik, yaratıcılık, cinsiyet, yenilik, kontrol odağı, başarı ihtiyacı, organizasyon ve liderlik becerileri, risk alma, kendine güven ve kendine sayg olarak (Marques vd., 2013) özetlemek mümkündür. Bunlardan başka, başarısızlık korkusu, girişimcilik niyetleri, algılanan yetenekler ve firsatlar gibi algısal göstergelerin tümü girişimcilik üzerinde önemli bir etkiye sahiptir, ancak bu etkiler bireylerin motivasyonuna göre farklılık göstermektedirler (Rusu, 2018). Bununla birlikte, literatürde girişimci ve yöneticiler arasındaki kişilik farklılıklarını güvenilebilir bir şekilde ayrıştırmanın mümkün olmadığına dair farkındalığın artı̧̧ıla, literatürün ilgisi daha çok girişimsel süreçlere ve faaliyetlere çevrilmiştir (Carsrud ve Brännback, 2011). 
Girişimcilik süreçlerini açıklamada başarma ihtiyacı ve özyeterlik inancına sıklıkla başvurulmaktadır. McClelland'ın, (1967) ihtiyaç kuramına göre insanları başarı, güç ve ilişki olmak üzere üç tür ihtiyaç motive etmektedir. Başarma ihtiyacı, üstün olma ve başarıya ulaşma güdüsü; güç ihtiyacı, diğerlerini kontrol edebilme ve etkili olabilme; ilişki ihtiyacı ise diğer kişilerle yakın ve dostça ilişkiler içinde olma anlamına gelmektedir. Buna göre başarma ihtiyacı yüksek olan kişilerin girişimcilik faaliyetlerine yönelmeleri daha olasıdır (Aramand, 2012).

Özyeterlik teorisi ise, bir başarım göstermek üzere gerekli faaliyetleri örgütleyebilme ve başarabilme ile ilgili olarak kişinin kendine dair yargısını açıklamaktadır (Bandura, 1994). Bu teoriye göre, kişinin bir görevi başarılı bir şekilde yerine getirme kabiliyeti, öz yeterliliği ile olumlu yönde ilişkilidir. Özyeterlik inancı, insanların kendilerini nasıl hissettiğini, düşündüğünü, motive ettiğini ve davrandığını belirlemektedir (Aramand, 2012). Araştırmalar ayrıca, bireyin öz yeterliliğinin, kişinin girişimci riskler alma istekliliğini artırdığını göstermektedir.

Araştırmamızın ana teması olan girişimcilik motivasyonu, girişimcilik süreçlerinin hem ekonomik hem de psikolojik ve davranışsal yönlerine dikkat çeken bir olgudur. Kişilerin girişimcilik davranışlarına yön veren faktörleri yalnızca ekonomik veya yalnızca psikolojik bir bakış açısı ile ele almak yerine her iki boyutu kapsayan bir yaklaşım daha ayrıntılı bir anlayış ortaya koyabilir.

\section{GİRIŞ̧iMCILIK MOTIVASYONU}

Girişimciliği bir süreç olarak ele alan çalışmalarda dört aşamadan sıklıkla bahsedilmektedir (Vangelderen vd., 2005). İlk aşama, bir girişime başlama niyetinin gelişimi ile ilgilidir. İkinci aşamada girişimci bir firsat tanınır ve bir iş kavramı geliştirilir. Üçüncü aşamada kaynaklar bir araya getirilir ve organizasyon ortaya çıkarılır. Son aşamada ise organizasyon piyasada mübadele etmeye başlar. Bununla birlikte insanlar arasındaki isteklilik ve hareket etme yeteneklerindeki değişimin girişimcilik süreci üzerinde önemli etkileri söz konusudur (Shane vd., 2012). Girişimcilik motivasyonu faktörleri ile işin büyümesi arasındaki ilişkiyi anlamak, bir iş kurma ve bir işletmenin girişimcilik süreci hakkında bilgi sağladığ1 için önemlidir.

Bir eylemin amacı veya psikolojik nedeni olarak motivasyon, hayatta kalmak, başarılı olmak ve başarısızlıktan kaçınmak için belirli davranışlara yol açar ve bir kişinin harekete geçmesine neyin neden olduğu sorusunu açıklamak için kullanılır. Ayrıca, bazı yazarlar motivasyonların niyet-eylem bağlantısını etkinleştirmeye hizmet edebileceğini öne sürmektedir (Carsrud ve Brännback, 2011).

Zimmerman ve Chu (2013) yaptıkları araştırmada, girişimciler arasında bir işletme kurmaya yönelik motivasyon faktörlerinin kontrol odağı, bağımsızlık, deneyim, eğitim, gelir yaratma, tanınma ve iş güvenliği olduğuna değinmişlerdir. Girişimci motivasyon faktörleri ile firmanın büyümesi arasındaki ilişkinin anlaşılması, işyerinde proaktifliği ve yaratıcılığı teşvik eden bir çalışma ortamı yaratmanın önemini bildirdiği için gereklidir (Okangi, 2018). Bu sebeple 
girişimcilik sürecini anlamak için girişimcilerin kararlarının ardındaki motivasyonu tanımlamak gerekmektedir.

Girişimcilik motivasyonu, insanları hedeflere doğru harekete geçirdiğinden işletmelerin girişim süreçleri üzerinde etkili olan bir güçtür (Okangi, 2018). Her istek veya hevesin girişimciliğe dönüşememesi, başarısızlık veya vazgeçme gibi olumsuz sonuçların yarattığı maliyetler, motivasyon faktörlerini önemli bir belirleyici olarak karşımıza çıkarmaktadır. $\mathrm{Bu}$ yüzden potansiyel girişimcileri tanımak, onların başarı ve risk algılarını motivasyon faktörleri çerçevesinde değerlendirmek önemlidir (Özdemir, 2010).

Girişimcilik motivasyonu, örgütleri, insanları veya fikirleri olabildiğince hızlı ve bağımsız bir şekilde organize etme, manipüle etme ve yönetme arzusu veya eğilimini ifade etmektedir (Johnson, 1990). Carsrud ve Brännback, (2011) biri kökünü psikolojiden alan diğeri ise ekonomi temelli olan ve birbirleriyle çatışma halinde iki motivasyon teorisi okulu olduğunu belirtmiştir. Bu motivasyon teorileri şu üç soruyu cevaplamayı amaçlamaktadır: "Bir kişiyi harekete geçiren şey nedir?", "Kişiye bir davranışı diğerine tercih ettiren şey nedir?", "Neden farklı insanlar aynı motivasyonel uyaranlara farklı tepkiler vermektedir?" .

Fikirler ve eylem arasındaki ilişkiyi anlamak, girişimcilik süreçlerini anlamak için önemlidir. Planlı davranış teorisi (Ajzen, 1991) bir kişinin bir faaliyete niyetlenmesini o faaliyetin ortaya çıkmasındaki en önemli tahmin edici olarak kabul etmektedir. Carsrud ve Brännback, (2011) hedeflerin gelecekte neler olabileceğinin zihinsel temsilleri olduğunu ve insanların vazgeçmemelerini sağladıklarına değinmiştir. Hedefler, insanları niyet ve eylem arasında önemli bir bağlant1 görevi gören şekillerde harekete geçirmektedirler. Bununla birlikte niyetler hemen eyleme yol açmaz, karşılıklılık vardır; tutumlar davranışı, davranışlar tutumu etkilemektedir.

Girişimcilik motivasyonu temel teorileri, güdüleme (drive) teorileri ve özendirme (incentive) teorileri olmak üzere iki ana kategoriye ayrılabilir (Fayolle vd., 2014). Güdüleme teorileri, yaşadığı gerilimi azaltmak için bireyi yeni bir girişim başlatmaya motive etme gücüne sahip olan örneğin, başarı veya özerklik gibi bir içsel ihtiyacın olduğunu öne sürmektedir. Buradan, iç gerilimin daha yüksek girişimcilik niyetine yol açabileceği iddia edilebilir. Öte yandan, özendirme teorileri, insanların dışsal ödüller yüzünden bir şeyler yapmaya motive olduklarını öne sürmektedirler. Örneğin, girişimciler esneklik, gelir veya prestij gibi teşviklerin bir karması ile motive edilebilmektedirler ve bu da girişimcilik niyetlerinin eyleme dönüşmesinin açıklanmasında önemli olabilir (Fayolle vd., 2014)

Collins ve vd. (2004), alanla ilgili makalelerin meta-analizini yaptıkları araştırmalarında girişimcilik motivasyonlarının girişimcilik kariyer yollarının seçimi ile anlamlı ve pozitif olarak ilişkili olduğu sonucuna ulaşmışlardır. Hessels vd. (2008), servet artırma güdüsünün, sosyo-ekonomik değişkenler ve girişimcilik niyetleri arasındaki ilişkiye aracılık ettiğini ve servet artırma güdüsü yüksek olan girişimcilerin daha fazla olduğu ülkelerde yüksek iş-büyüme ve ihracata yönelik girişimciliğin daha yaygın olduğunu bulmuşlarıdır. Yazarlara göre bireysel girişimcilik motivasyonunun türü, işletmenin hedefleri ve isteklerini belirlerken bu 
da makro-ekonomik sonuçları belirlemektedir. Girişimcilik eğitimlerinin ya da verilecek hibelerin katılımcı motivasyonunu tarif ederek tanımlanması açısından da bunun önemli bir sonuç olduğu görülmektedir.

Girişimcilik konusunda yapılan ilk çalışmalardan itibaren yenilikçilik önemli bir özellik olarak öne çıkmaktadır. Girişimci ve girişimcilik tanımlarının çoğunda yenilikçiliğe yapılan vurguyu görmek mümkündür. Bununla birlikte girişimcilik motivasyonu ve işletme yenilikçiliği arasındaki ilişkileri ele alan çalışmalar yapılmıştır. Örneğin Polat (2011), turizm işletmeleri üzerinde gerçekleştirdiği araştırmada işletmenin türüne göre ve işletme sahip ya da yöneticisinin eğitimine göre girişimcilik motivasyonunun farkl1lık gösterdiği, sonucuna ulaşmıştır. Ayrıca para ve büyüme odaklı motivasyona sahip işletmelerde süreç yeniliği ile ürün ve hizmet yeniliğinin de olumlu yönde etkilendiği görülmüştür.

\section{A. Girişimcilik Motivasyonu ve Çevresel Koşullar}

Bazı bireyler algılanan bir pazar fırsatına tepki verirlerken, diğerleri ise bazı olumsuz koşullar nedeniyle bir iş kurmaya zorlanırlar. Literatürün farklı ülkelerdeki girişimcilik faaliyeti üzerinde etkili olan faktörler ve girişimcilik motivasyonuna ilgisinin nedeni de buradan kaynaklanmaktadır. Girişimcilik çevresi, belirli bir toplumun girişimcilik ruhu ve kültürünün yanı sıra girişimcilik başlangıçlarını destekleyen kurumların varlığını değerlendirmeye odaklanmaktadır (Vidic vd., 2016). Bu tür bir bakış açısı girişimcilik davranışlarının sektör, ekonomi, ülke veya bölge bağlamında değişebileceğine dikkat çekmektedir.

Dubini (1989), bireylerin motivasyonları ile çevreye ilişkin algıları arasındaki ilişkiyi incelediği çalışmasında algılanan çevreyi üç başlıkta tanımlamıştır. Bunlardan ilki verimli altyapılar ile yerleşik sermaye piyasalarının olduğu, girişimciliği özendiren cömert çevrelerdir. İkincisi, özellikle yeni işletme kurmayı teşvik eden bir altyapının olduğu destekleyici çevrelerken, üçüncüsü de alt yapının ve sermayenin olmadığı kıt çevrelerdir. Girişimcilik türleri ve motivasyonu her bir çevrede önemli ölçüde farklılık göstermektedir.

Benzer şekilde Rusu (2018), girişimcilik motivasyonunun, bir ülkenin ekonomik gelişme düzeyinden ve toplam vergi, işsizlik, enflasyon oranlarından ve finansal kaynaklara erişimden etkilendiğini ifade etmiştir. Hessels vd., (2008) ise bir ülkenin sosyal güvenlik düzeyinin yüksekliği ile yenilikçi ve ihracata yönelik girişimciliğin yaygınlığı arasında olumsuz yönde ilişkili olduğunu bulmuşlardır. Başka bir ifade ile bir ülkede sosyal güvenlik şemsiyesi altında yaşayanların sayısı ne kadar çok ise o ülkede yenilikçi, büyüme potansiyeli olan ve ihracata yönelik iş yapan girişimci sayısı o kadar azdır.

Minola vd. (2016), girişimciliği motive eden bireysel faktörlerin, hem yaş hem de kültür ile sistematik olarak iç içe geçtiğini ve birbirine yerleşik olduğunu bulmuşlardır. Stephan vd.. (2015), girişimcilik motivasyonlarının girişimcilerin yaş, cinsiyet, eğitim ve hane halkı geliri gibi demografik unsurlarla ilişkili olduğunu belirtmektedir. Aynı zamanda, yeni iş başlangıcında, bireyin bir işte çalışma durumu, önceki işinden geçişi, aile sorumlulukları, rol modelleri gibi 
kişisel durumlarıyla, işe tek başına girişmek, firmanın sektörü gibi başlangıç düzeyindeki girişimin özellikleri de etkili olmaktadır (Stephan vd., 2015).

Davidsson ve Delmar (1992), doğuştan girişimci yönelime sahip olmayan kişilerin bile, toplum tarafindan sağlanan teşvikin olumlu ve destekleyici olması halinde girişimci olabileceklerini öne sürmüşlerdir. Yazarlara göre kültür, örgün eğitim ve kamu politikaları, girişimcilik oryantasyonu ve motivasyonu açısından da önemli bir rol oynamaktadır.

\section{B. Girişimcilik Motivasyonu Sınıflamaları ve Faktörleri}

Girişimcilik motivasyonu yazınında kişileri girişimciliğe yönelten itme ve çekme faktörlerine sıklıkla değinilmektedir. İtme faktörleri arasında aile gelirini artırma ihtiyac1, maaş temelli bir işten memnuniyetsizlik, uygun bir iş bulma ve ailenin sorumluluklarını yerine getirme ihtiyacı gibi unsurlar yer almaktadır. Çekme faktörleri ise bağımsızlık ihtiyacı, kendini gerçekleştirme, toplumdaki statü ve itibarı artırma gibi unsurları içermektedir (Yalçın ve Kapu, 2008). Amit ve Muller (1995), itme faktörlerinin etkisindeki girişimcileri, bulundukları konumlarından memnun olmayan, kendi girişimcilik özellikleriyle ilgili olmayan nedenlerin bir girişime başlamaya ittiği kişiler olarak tanımlamışlardır. Çekme girişimcileri ise, yeni girişim fikrinin cezbettiği ve iş fikrinin çekiciliği ve kişisel etkileri nedeniyle girişim faaliyetine başlayan kimselerdir. Yazarlar araştırmalarında çekme etkisindeki girişimcilerin, itme etkisindeki girişimcilerden daha başarılı olduğu sonucuna ulaşmışlardır (Amit ve Muller, 1995).

Benzer şekilde "firsat ve gereksinim sinıflaması", yazındaki yine eski kavramsallaştırmalardan bir diğeridir. Bu sınıflama, girişimciliği sadece firsattan yararlanma olarak gören olumlu bir içerikten başka, işsiz oldukları veya şu anki işlerinden mutsuz oldukları için bir iş kuranları dikkate alarak iş kaybıyla baş etmek gibi bir zorunluluğun da bu tercihe yol açabileceğini kabul etmektedir (Stephan vd., 2015).

Girişimcinin niyeti ve belirli firsatların peşinde koşması önemlidir ancak yine de bu niyetleri harekete geçirmek veya bu firsatları kullanmak belirli bir motivasyon gerektirmektedir. Gereklilik girişimcileri, hayatta kalmak üzere, başarısız olmak konusunda daha fazla endişe duymaktadırlar. Bu noktada temel motivasyon, kişinin kendini ve ailesini destekleyebilecek kadar para kazanmaktır. Gatewood (1995), içsel yönelimlerle iş kumaya girişen kadınların (örneğin özerkliğe ihtiyaç) ve dışsal yönelimler sebebiyle girişen erkeklerin (piyasadaki bir ihtiyacı algılayanlar gibi), başlangıç öncesi aşamayı başarıyla tamamlama şanslarının daha yüksek olduğunu bulmuştur.

Tekin (1999), insanları girişimci olmaya yönelten motivasyonları; tanınma ve prestij kazanma, yaptıklarıyla toplumda iz bırakma, bir fikri ya da düşünceyi kendi işini kurarak gerçekleştirme, çok para kazanma, gelir düzeyini artırma ve refah içinde yaşama, başka insanların göremedikleri ya da uğraşmadıkları işleri keşfedip bu fırsattan yararlanabilmek için işyeri kurma isteği olarak açıklamaktadır.

Bourlès ve Cozarenco, (2017) Fransa' da mikro finans kullanan girişimciler üzerinde yaptıkları araştırmada bu gruptakilerin çoğunun gereksinim girişimcileri olduğunu ve bunların kredilerini geri ödemede çok daha fazla zorluk yaşadıklarını 
bulmuşlardır. Yazarlar eşit hayatta kalma şansına rağmen, mikro girişimcilerin finansal taahhütlerle yüzleşme zorunluluğunu işletmelerinin sinırlı büyüme potansiyeliyle ilişkilendirmişlerdir.

Shane vd. (2012), girişimcilik motivasyonunun başarma ihtiyacı, risk alma eğilimi, çaba gösterme, denetim odağı (bireylerin eylemlerinin veya kişisel özelliklerinin sonuçları etkilediğine inanma ölçüsü), öz-yeterlik, belirsizlik toleransı ve hedef belirleme ile ilişkili olduğuna dikkat çekmiştir. Ayrıca yazarlar bağımsızlık, bir örgüt kurma ve onu kârlı hale getirme sürecini sevmek anlamında egoist tutkunun da önemine dikkat çekmişlerdir.

Stephan vd., (2015) girişimcilik motivasyonunun çok boyutlu tipolojilerinden ilki olan başarl, meydan okuma ve ögrenme boyutunun, girişimcilik yoluyla kişisel gelişim arzusunun yanı sıra anlamlı iş, sorumluluk sahibi olmak ve iş kurma/sürdürme çabasıyla öğrenme gibi yönleri içerdiğini belirtmişlerdir. Bağımsızlık ve özerklik boyutu ise kişinin çalışma zamanı ve içeriğini kendi kontrolünde tutabilmesi, bağımsız kararlar vermesi ve işi kişisel hayatıyla birleştirebilecek bir esnekliğe sahip olmasını içermektedir. Gelir güvenliği ve finansal başarı boyutu girişimcilikten elde edilen finansal getirinin önemini gösterirken, tanınma ve statü boyutu, bir kişinin girişimci olarak çalışması için diğerleri tarafından tanınma ve saygı görme isteği gibi sosyal statü ile ilgili hususları içermektedir. Aile ve roller boyutu, bir aile geleneğini sürdürme arzusunun yanı sıra diğger rol modellerini takip etme isteği ile ilgilidir ve aynı zamanda bir aile mirası oluşturmayı da vurgulamaktadır. Memnuniyetsizlik boyutu, kişinin önceki işiyle ilgili memnuniyetsizliklerden kaynaklanan girişimcilik motivasyonunu açıklamaktadır. Toplum ve sosyal motivasyonlar boyutu, sosyal girişimcilik gibi hayırseverlik veya girişimcinin içinde yaşadığı topluma katk1 sağlama arzusunu içermektedir (Stephan vd., 2015).

\section{METODOLOJI VE ARAŞTIRMA BULGULARI}

Araştırmanın evreni Antalya ilinde Ağustos - Eylül - Ekim 2016 aylarında KOSGEB Uygulamalı Girişimcilik Eğitimine katılan 750 adaydan oluşmaktadır. Araştırmada \% 95 güven, \% 2 hata payı ile 589 kişiye, kolayda örneklem yöntemiyle yüz yüze anket uygulanmış ve girişimci adaylarının girişimcilik motivasyonlarının açıklanması amaçlanmıştır. Seçili bazı demografik değişkenler bakımından girişimcilik motivasyonunun değişimi betimsel istatistikler, $\mathrm{t}$ testleri, ANOVA ve faktör analizleriyle ortaya çıkarılmıştır.

Araştırmada veri toplama yöntemi olarak Vijaya ve Kamalanabhan (1998) tarafından geliştirilen Girişimcilik Motivasyonu ölçeği kullanılmıştır. Ölçek Türkçeye çevrildikten sonra konuyla ilgili çalışan akademisyenlerden görüş alınarak düzenlemeler yapılmıştır. Pilot bir uygulama ile anketin geçerlilik ve güvenilirliği test edilmiş ve gerekli düzenlemeler yapıldıktan sonra alan araştırmasına başlanmıştır. 


\section{A. Betimsel Bulgular}

Araştırmaya katılanların \%37,7'sinin 26- 35, \%34,1'inin ise 36- 45 yaşları arasında olduğu görülmektedir. Buna göre araştırmaya katılanların büyük çoğunluğunun genç- orta yaş dönemindeki kişiler olduğu söylenebilir.

Cinsiyet dağılımlarına bakıldığında katılımcıların büyük oranda eşit dağıldığı görülmektedir. Cinsiyet dağılımı içerisinde girişimcilik eğitimi almak isteyen kadın ve erkeklerin sayılarının neredeyse eşit olması, kadınların girişimciliğe olan ilgisinin yaygınlaştığına yönelik küçük bir izlem oluşturabilir.

Tablo 1: Katılımcıların Demografik Özellikleri ve Girişimcilik Tecrübeleri

\begin{tabular}{|c|c|c|}
\hline Yaş & Say1 & Yüzde \\
\hline $18-25$ & 76 & 12,9 \\
\hline $26-35$ & 222 & 37,7 \\
\hline $36-45$ & 201 & 34,1 \\
\hline 46- 55 & 78 & 13,2 \\
\hline $56-65$ & 12 & 2,0 \\
\hline Toplam & 589 & 100,0 \\
\hline \multicolumn{3}{|l|}{ Cinsiyet } \\
\hline Kadın & 293 & 49,7 \\
\hline Erkek & 296 & 50,3 \\
\hline Toplam & 589 & 100,0 \\
\hline \multicolumn{3}{|l|}{ Eğitim Durumu } \\
\hline İlkokul & 44 & 7,5 \\
\hline Ortaokul & 65 & 11,0 \\
\hline Lise & 187 & 31,7 \\
\hline Önlisans & 80 & 13,6 \\
\hline Lisans & 198 & 33,6 \\
\hline Lisansüstü & 15 & 2,5 \\
\hline Toplam & 589 & 100,0 \\
\hline \multicolumn{3}{|l|}{$\begin{array}{l}\text { Girişimcilik } \\
\text { Tecrübesi }\end{array}$} \\
\hline Evet & 238 & 40,4 \\
\hline Hayır & 351 & 59,6 \\
\hline Toplam & 589 & 100,0 \\
\hline Y1llık Gelir & Sayı & Yüzde \\
\hline 10.000- TL ve altı & 77 & 13,1 \\
\hline $10.001-20.000 \mathrm{TL}$ & 106 & 18,0 \\
\hline $20.001-30.000 \mathrm{TL}$ & 68 & 11,5 \\
\hline $30.001-40.000 \mathrm{TL}$ & 54 & 9,2 \\
\hline $40.001-50.000 \mathrm{TL}$ & 20 & 3,4 \\
\hline 50.001 TL ve üstü & 41 & 7,0 \\
\hline Gelirim yok & 216 & 36,7 \\
\hline Cevap Yok & 7 & 1,2 \\
\hline Toplam & 589 & 100,0 \\
\hline
\end{tabular}

Katılımcıların \% 49,7'si üniversite eğitimi almıştır ve \% 31,7'si lise mezunudur. Katılımcıların yaklaşık olarak yarısı, formel bir mesleki eğitim almaları ve ücretli bir işte çalışma imkanları bu eğitimlere sahip olmayanlara göre daha fazla mümkün olduğu halde, kendileri için girişimciliği bir kariyer olarak görmektedirler.

Araştırmaya katılan adayların \% 59,6'sının daha önce herhangi bir girişimcilik tecrübesi olmadığı görülmektedir. Daha önceden bir girişimcilik 
tecrübesi olan \% 40,4 kesim öncelikli olarak hibe başvurusu yapabilmek, ardından da girişimcilik bilgi ve becerilerini geliştirmek amacıyla eğitim almaktadırlar.

Araştırma katılımcılarının \% 36,7'sinin herhangi bir gelirinin bulunmadığ1 görülmektedir. Oysa bir iş kurmak için gerekli ekonomik sermaye, girişimcilik faaliyetinin başarısını doğrudan etkileyecek bir faktör olarak görülmektedir. Bu açıdan bakıldığında, KOSGEB'in uygulamalı girişimcilik eğitimi alan adaylara hibe başvurusunda bulunma hakkı tanımasının, girişimci adaylarının gelirleri olmasa bile bu eğitimi alarak girişimciliğe başlamasında bir motivasyon kaynağ1 oluşturduğu söylenebilir.

\section{B. Faktör Analizi Bulguları}

Araştırmada kullandığımız ve Vijaya ve Kamalanabhan (1998) tarafından geliştirilen girişimcilik motivasyonu ölçeğinde yazarlar faktör analizi uygulamışlardır. Vijaya ve Kamalanabhan’ın (1998) araştırma sonuçlarına göre kişileri girişimciliğe yönelten faktörler girişimcilik, çalışma, sosyal, bireycilik ve

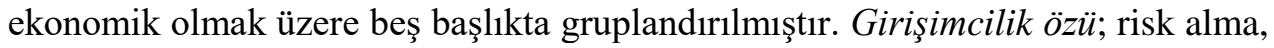
bağımsızlık, diğerlerine istihdam sağlama, girişimcilik desteklerinden faydalanma, topluma hizmet etme gibi motivleri içermektedir. Çalışma öz $\ddot{u}$; yetenek ve potansiyelinden faydalanma, kariyerinde karar verme becerisini kullanma, çabalarında yaratıcı ve yenilikçi olma ile ilişkilidir ve bu boyutun başarma ihtiyacı ile doğrudan ilgisi vardır. Toplumsal öz, lider olma, başkaları üzerinde güç ve nüfuza sahip olma, yüksek sosyal statü ve saygı kazanma ile ilişkilidir. Bireycilik özü, kişisel olarak tercih edilen bir çalışma ve yaşam tarzını arzulamayı içeren bireyselci bir içeriğe sahiptir. Ekonomik öz ise para sıkıntısı ve borçlardan kurtulmak, ailesi için gelir kazanmak ve bunu yaparak sosyal merdivenleri tırmanmak gibi bir içeriğe sahiptir.

Ölçeğin Türkçe çevirisinden sonra yapılan pilot çalışmada, ölçeğin faktör yüküne ilişkin düşük ifade ve boyut korelasyonuna sahip olmadığı görülmüş ve mevcut ölçek üzerinde herhangi bir değişiklik yapılmamıştır.

Ölçeğin Cronbach's Alfa değeri literatürde belirtilen şekilde (Nunnally, 1978) 0,70'in üzerinde olup çalışmamız kapsamında 0,928 olarak tespit edilmiştir. Ölçeğin yapı geçerliliğini incelemek amacıyla yapılan faktör analizi sonucunda, hem faktör analizi için ön koşul olan hem de örneklem büyüklüğünün yeterli olduğunu gösteren KMO değeri hesaplanmıştır. Buna göre Tablo 2'de de görüleceği üzere KMO 0,916 olarak bulunmuştur. 
Tablo 2: Girişimcilik Motivasyon Kaynakları

\begin{tabular}{|c|c|c|c|c|c|}
\hline & $\begin{array}{l}\text { Ekonomik } \\
\text { odak }\end{array}$ & $\begin{array}{c}\text { Girişimci } \\
\text { odak }\end{array}$ & $\begin{array}{l}\text { Toplumsal } \\
\text { odak }\end{array}$ & $\begin{array}{l}\text { Çalışma } \\
\text { odağ } 1\end{array}$ & $\begin{array}{l}\text { Bireyci } \\
\text { odak }\end{array}$ \\
\hline Para sıkıntısından kurtulmak & 791 & & & & \\
\hline Aile gelirine katkıda bulunmak & ,730 & & & & \\
\hline Ailemi zengin etmek & ,716 & & & & \\
\hline $\begin{array}{l}\text { Çocuklarıma parasal açıdan istikrar } \\
\text { sağlamak }\end{array}$ & 698 & & & & \\
\hline Borçlarımı kapatacak parayı kazanmak & ,530 & & & & \\
\hline $\begin{array}{l}\text { İnsanlara istihdam sağlayarak yardım } \\
\text { etmek }\end{array}$ & & ,777 & & & \\
\hline Topluma iyi mal veya hizmetler sunmak & &, 710 & & & \\
\hline $\begin{array}{l}\text { Karar verme/ problem çözme becerilerimi } \\
\text { bir kariyerde fayda yaratmak için } \\
\text { kullanmak }\end{array}$ & & ,631 & & & \\
\hline Yaratıcı yenilikçi bir şeyler yapmak & &, 551 & & & \\
\hline $\begin{array}{l}\text { Devletin ya da diğer kurumların sunduğu } \\
\text { kredi veya desteklerde faydalanmak }\end{array}$ & & ,430 & & & \\
\hline $\begin{array}{l}\text { Risk alma becerimi etkili kullanarak } \\
\text { başar1lı olmak }\end{array}$ & & ,428 & & & \\
\hline $\begin{array}{l}\text { Başkalarıyla rekabet ederek en iyi } \\
\text { olduğumu kanitlamak }\end{array}$ & & & ,772 & & \\
\hline $\begin{array}{l}\text { Hiç kimseden bir eksiğim olmadığını } \\
\text { göstermek }\end{array}$ & & & ,710 & & \\
\hline Hayatın lükslerinin tadını çıkarmak & & & 611 & & \\
\hline İnsanların saygısını kazanmak & & &, 521 & & \\
\hline Yüksek sosyal statüye erişmek & & & ,499 & & \\
\hline Kendim için büyük servete kavuşmak & & & ,446 & & \\
\hline $\begin{array}{l}\text { Başkalarının yapmadığı bir şeyi yapma/ } \\
\text { başarma }\end{array}$ & & & 413 & & \\
\hline Lider olmak & & & & ,684 & \\
\hline İşletmecilik tutkumdan istifade etmek & & & &, 593 & \\
\hline $\begin{array}{l}\text { Doğuştan yeteneklerimi ve bir } \\
\text { uzmanlıktaki potansiyelimi kullanmak }\end{array}$ & & & &, 581 & \\
\hline Bir çalışan değil bir işveren olmak & & & &, 562 & \\
\hline İşten tam bir tatmin duymak & & & &, 535 & \\
\hline $\begin{array}{l}\text { Yeteneğime karşıllık en iyi parasal getiriye } \\
\text { sahip olmak }\end{array}$ & & & & ,430 & \\
\hline Bağımsız olmak & & & & &, 751 \\
\hline $\begin{array}{l}\text { Kendi tercihim olan bir iş ve yaşam tarzına } \\
\text { sahip olmak }\end{array}$ & & & & & ,604 \\
\hline $\begin{array}{l}\text { Monotonluktan kurtularak değişimi } \\
\text { yassamak }\end{array}$ & & & & &, 521 \\
\hline
\end{tabular}

Kaiser Meyer OlKin $(\mathrm{KMO})=, 916$ Bartlett's Test of Sphericity $=3681,087 \mathrm{p}=0,0, \mathrm{p}<0,05$

Faktör analizi sonucunda, para sıkıntısı, aile gelirine katk1, aileyi zengin etme, çocuklara parasal açıdan istikrar sağlama, borçları kapatma değişkenleri ekonomik odaklı motivasyon faktörü altında ve orijinal çalışmanın sonuçlarıyla tutarlı bir şekilde toplanmıştır. Literatür kısmında da değindiğimiz üzere ekonomik gereksinimler ile refaha kavuşma, girişimci olmak isteyenler için başta gelen unsur olarak tanımlanmaktadır. 
Kişilerin girişimci kişilik özelikleri ile bu yöndeki niyetlerini yansıtan girişimcilik odaklı motivasyon faktöründe ise istihdam sağlama, iyi mal veya hizmetler sunma, karar verme/ problem çözme becerileri ile fayda yaratma, yaratıcı-yenilikçi bir şeyler yapma, kredi veya desteklerden faydalanma, risk alma becerisi ile başarılı olma değişkenleri ise girişimcilik odaklı motivasyon faktörü altında toplanmıştır. Bu grup içerisinden yaratıcılık-yenilikçilik değişkeni, yaratıcı ve yenilikçi bir kişiliğe sahip olan bireylerin girişimciliği bir kariyer olarak değerlendirmesinden ötürü, anlaşılabilir bir şekilde aynı zamanda çalışmaya dair tutum faktörü içinde de yer almaktadır. Kaldı ki girişimcilik gibi bir iş geçişi hem geçmiş dönemler dizisi anlamında hem de hayal edilen gelecekteki bir yörünge anlamında kariyer bağlamında anlaşılmalıdır (Burton vd., 2016).

Toplumsal odakl motivasyon faktörü altında rekabet ederek en iyi olduğunu kanıtlama, kimseden bir eksiği olmadığını gösterme, hayatın lükslerinin tadını çıkarmak, insanların saygısını kazanma, yüksek sosyal statüye erişme, kendi için büyük servete kavuşma, başkalarının yapmadığı bir şeyi başarma değişkenleri toplanmıştır. Görüleceği üzere bu değişkenler bireyin toplumda işgal ettiği yer anlamında toplumsal statü ile diğerlerinin onu nasıl algıladığı ve bireyin diğerleriyle nasıl etkileşime girdiğine işaret eden olgulardır. Kendi için büyük servete kavuşma değişkeni aynı zamanda ekonomik odaklı motivasyon faktörü içinde de yer almıştır. Statünün önemli bir belirleyeni ekonomik olmakla birlikte tek başına yeterli olmayıp, saygınlık kazanma, becerilerini diğerlerine kanıtlama gibi boyutları da içermektedir.

Kişinin çalışmaya ve kariyere dair tutumlarını gözlemleyebileceğimiz çalışma odaklı motivasyon faktörü altında ise lider olma, işletmecilik tutkusundan fayda sağlama, yeteneklerini ve bir uzmanlıktaki potansiyelini kullanma, çalışan değil işveren olma, işten tam bir tatmin duyma, yeteneğe karşılık en iyi parasal getiriye sahip olma değişkenleri bir araya gelmiştir. Orijinal çalışmada lider olma ve bir işveren olma boyutları toplumsal öz faktörü içinde yer alırken bizim çalışmamızda bu grup altında yer alması kültürel farklılıkla ilişkilendirilebilir. Bununla birlikte bu iki faktörün çalışmanın doğasıyla daha yakından ilişkili olması bulgularımızın tutarlılığını güçlendirmektedir.

Bireyci odakl motivasyon faktörü ise bağımsız olma, kendi tercihi olan bir işe ve yaşam tarzına sahip olma ve monotonluktan kurtularak değişimi yaşama değişkenlerinden oluşmaktadır. Bu faktör girişimciliği kendi bağımsızlığını elde ederek, alışılmış olanın ya da çoğunluğun yaptığının dışına çıkmanın bir yolu olarak gören bir anlayışı ve motivasyonu açıklamaktadır.

\section{T Testleri}

$\mathrm{Bu}$ kısımda cinsiyet ve girişimcilik tecrübelerinin, girişimcilik motivasyonları üzerinde anlamlı bir fark gösterip göstermediğine bakılmaktadır. 
Tablo 3: Cinsiyete Göre Girișimcilik Motivasyonlarıyla İlișkisi

\begin{tabular}{|c|c|c|c|c|c|c|}
\hline & & & & & & \\
\hline & Cinsiyet & $\mathrm{N}$ & $\mathrm{X}$ & SS & $\mathrm{F}$ & $\mathrm{P}$ \\
\hline \multirow{2}{*}{ Ekonomik Motivasyon } & Kadın & 293 & 2,7152 & ,04869 & \multirow{2}{*}{10,160} & \multirow{2}{*}{,002 } \\
\hline & Erkek & 296 & 3,0480 & 05799 & & \\
\hline \multirow{2}{*}{ Girişimci Motivasyon } & Kadın & 293 & 1,9899 & ,04558 & \multirow{2}{*}{3,036} & \multirow{2}{*}{,082 } \\
\hline & Erkek & 296 & 2,0118 & ,04329 & & \\
\hline \multirow{2}{*}{ Toplumsal Motivasyon } & Kadın & 293 & $3,0235^{*}$ & ,05237 & \multirow{2}{*}{1,294} & \multirow{2}{*}{, $256^{*}$} \\
\hline & Erkek & 296 & $3,1400^{*}$ & ,05485 & & \\
\hline \multirow{2}{*}{ Çalışma Motivasyonu } & Kadın & 293 & $2,1349 *$ & ,04366 & \multirow{2}{*}{, 010} & \multirow{2}{*}{,919* } \\
\hline & Erkek & 296 & 2,1504 &, 04545 & & \\
\hline \multirow{2}{*}{ Bireyci Motivasyon } & Kadın & 280 & 2,0179 & ,04945 & \multirow{2}{*}{7,891} & \multirow{2}{*}{, 005} \\
\hline & Erkek & 292 & 2,2911 & ,05626 & & \\
\hline
\end{tabular}

Tablo 3 incelendiğinde cinsiyet dağılımlarının girişimcilik motivasyonları bakımından toplumsal $(p>0,05)$ ve çalışma motivasyonu $(p>0,05)$ ile anlamlı bir farklılık gösterdiği, bu alanlarda erkeklerin kadınlara göre daha yüksek motivasyonda olduğu gözlemlenmiştir. Diğer taraftan cinsiyet farklılıklarının ekonomik, girişimci ve bireyci motivasyon faktörleri üzerinde anlamlı bir farklılık oluşturmadığ1 görülmektedir.

Tablo 4: Girişimcilik Tecrübesinin Girişimcilik Motivasyonlarıyla İlişkisi

\begin{tabular}{|c|c|c|c|c|c|c|}
\hline & $\begin{array}{c}\text { Girişim } \\
\text { Tecrübesi }\end{array}$ & $\mathrm{N}$ & $\mathrm{X}$ & SS & $\mathrm{F}$ & $\mathrm{P}$ \\
\hline \multirow{2}{*}{ Ekonomik Motivasyon } & Var & 238 & 3,0873 & ,98482 & \multirow{2}{*}{5,711} & \multirow{2}{*}{, 017} \\
\hline & Yok & 351 & 2,7435 & ,87213 & & \\
\hline \multirow{2}{*}{ Girişimci Motivasyon } & Var & 238 & 2,0962 & ,83049 & \multirow{2}{*}{6,908} & \multirow{2}{*}{,009 } \\
\hline & Yok & 351 & 1,9363 &, 70588 & & \\
\hline \multirow{2}{*}{ Toplumsal Motivasyon } & Var & 238 & 3,2133 & 1,00288 & \multirow{2}{*}{10,562} & \multirow{2}{*}{, 001} \\
\hline & Yok & 351 & 2,9930 & ,85204 & & \\
\hline \multirow{2}{*}{ Çalışma Motivasyonu } & Var & 238 & 2,2330 & 84220 & \multirow{2}{*}{4,655} & \multirow{2}{*}{, 031} \\
\hline & Yok & 351 & 2,0814 &, 70128 & & \\
\hline \multirow{2}{*}{ Bireyci Motivasyon } & Var & 226 & $2,3960^{*}$ & ,96000 & \multirow{2}{*}{2,389} & \multirow{2}{*}{, $123 *$} \\
\hline & Yok & 346 & $2,0014 *$ & ,83757 & & \\
\hline
\end{tabular}

Kişilerin girişimcilik tecrübesinin olup olmamasının girişimcilik motivasyonlarında anlamlı bir farklılığa yol açıp açmadığını gösteren Tablo 4'de, ekonomik, girişimci, toplumsal, çalışma boyutlarında girişimcilik tecrübesinin anlamlı bir farklılık ortaya koymadığı görülmüştür. Diğer taraftan daha öncesinde girişimcilik tecrübesi olup, girişimcilik eğitimlerine katılanların bireyci motivasyon üzerinde anlamlı bir farklılığa sahip olduğu görülmektedir. Bir başka ifadeyle girişimcilik tecrübesi olanlar, girişimcilik tecrübesi olmayanlara göre daha fazla bireyci motivasyona sahiptirler.

\section{ANOVA Testleri}

ANOVA testleri yapılırken gözetilen şartlar bakımından varyansların homojen dağılması ilkesine göre bu bölümde değerlendirilen bağımlı değişkenler öncelikli olarak bu koşulu sağlayıp sağlamadıklarına göre ayrılmış, tablolar bu ilkeye uygun olarak kolay anlaşılır olması maksadıyla bölünmüştür. 
Tablo 5: Y1llık geliri düzeyi ile girişimcilik motivasyonları arasındaki ilişkiler (Varyansları homojen dağılan motivasyonlar)

\begin{tabular}{|c|c|c|c|c|c|c|}
\hline $\begin{array}{l}\text { Bağımlı } \\
\text { Değişken }\end{array}$ & Y1llık Gelir (i) & Yillık Gelir (j) & Fark & $\begin{array}{l}\text { Ortalamanın } \\
\text { Karesi }\end{array}$ & $\mathrm{F}$ & $\mathrm{P}$ \\
\hline \multirow{10}{*}{$\begin{array}{l}\text { Toplumsal } \\
\text { Motiv. }\end{array}$} & 10.000- TL ve alt & 50.001 TL ve üstü &,$- 59629 *$ & \multirow{10}{*}{$\begin{array}{l}\text { Gruplar arası: } \\
2,593 \\
\text { Grup içi: } 0,831\end{array}$} & \multirow{10}{*}{3,12} & \multirow{10}{*}{0,05} \\
\hline & $10.001-20.000 \mathrm{TL}$ & 50.001 TL ve üstü &,$- 62738^{*}$ & & & \\
\hline & $20.001-30.000 \mathrm{TL}$ & 50.001 TL ve üstü &,$- 59803^{*}$ & & & \\
\hline & $30.001-40.000 \mathrm{TL}$ & $50.001 \mathrm{TL}$ ve üstü &,$- 57012 *$ & & & \\
\hline & \multirow{5}{*}{50.001 TL ve üstü } & 10.000- TL ve alt &, $59629 *$ & & & \\
\hline & & $10.001-20.000 \mathrm{TL}$ &, $62738^{*}$ & & & \\
\hline & & $20.001-30.000 \mathrm{TL}$ &, $59803 *$ & & & \\
\hline & & $30.001-40.000 \mathrm{TL}$ &, $57012 *$ & & & \\
\hline & & Gelirim yok &, $63033^{*}$ & & & \\
\hline & Gelirim yok & $50.001 \mathrm{TL}$ ve üstü &,$- 63033^{*}$ & & & \\
\hline \multirow{11}{*}{$\begin{array}{c}\text { Bireyci } \\
\text { Motiv. }\end{array}$} & 10.000- TL ve altı & 50.001 TL ve üstü &,$- 71671 *$ & \multirow{11}{*}{$\begin{array}{l}\text { Gruplar arası: } \\
4,647 \\
\text { Grup içi: } 0,784\end{array}$} & \multirow{11}{*}{5,929} & \multirow{11}{*}{0,00} \\
\hline & $10.001-20.000 \mathrm{TL}$ & 50.001 TL ve üstü &,$- 64559^{*}$ & & & \\
\hline & $20.001-30.000 \mathrm{TL}$ & 50.001 TL ve üstü &,$- 76064^{*}$ & & & \\
\hline & $30.001-40.000 \mathrm{TL}$ & 50.001 TL ve üstü &,$- 82310^{*}$ & & & \\
\hline & \multirow{6}{*}{50.001 TL ve üstü } & 10.000- TL ve altı &, $71671^{*}$ & & & \\
\hline & & $10.001-20.000 \mathrm{TL}$ &, $64559^{*}$ & & & \\
\hline & & $20.001-30.000 \mathrm{TL}$ &, $76064^{*}$ & & & \\
\hline & & $30.001-40.000 \mathrm{TL}$ &, $82310^{*}$ & & & \\
\hline & & $40.001-50.000 \mathrm{TL}$ &, 10010 & & & \\
\hline & & Gelirim yok &, $77116^{*}$ & & & \\
\hline & Gelirim yok & 50.001 TL ve üstü &,$- 77116^{*}$ & & & \\
\hline
\end{tabular}

Yapılan ANOVA (Post Hoc Tukey) testinde varyansların homojenliği, sadece girişimci ve toplumsal motivasyon kaynaklarında görülmüş ancak ANOVA testinde girişimci motivasyonun $\mathrm{p}$ değeri 0,186 olarak bulunmuştur ve alfa değerinin üzerinde kaldığı için yıllık gelir durumları ile girişimci motivasyon arasında anlamlı bir fark görülmediği ortaya çıkmıştır. Diğer taraftan toplumsal motivasyon düzeyi yıllık gelir durumlarına göre anlamlı bir farklılık göstermiş ve Tablo 5'de paylaşılmıştır. Buna göre 50 bin TL ve üzerinde geliri olanlar, geliri olmayanlara ve geliri olan tüm gruplara göre toplumsal motivasyondan daha fazla etkilenmektedir. Dolayısıyla yılda 50 bin TL üzerinde gelir sahibi olanlar, başkalarıyla rekabet etme, hiç kimseden bir eksiği olmadığını gösterme, hayatın lükslerinin tadını çıkarma, insanların saygısını kazanma, yüksek sosyal statüye ulaşma, kendisi için büyük bir servete kavuşma ve başkalarının yapmadığı /yapamadığı bir şeyler yapmaya daha çok motive olmuş durumdadır. Diğer taraftan 50 bin TL ve üzerinde yıllık geliri olan grup, bağımsız olma, kendi tercihi olan bir iş ve yaşam tarzına sahip olma ve monotonluktan kurtularak değişimi yaşama istekleri bakımından bireyci motivasyona diğer gelir gruplarından ve geliri olmayanlardan daha yüksek seviyede sahiptir. 
Tablo 6: Yıllık gelir düzeyi ile girişimcilik motivasyonları arasındaki ilişkiler (Varyansları homojen dağılmayan motivasyon faktörleri)

\begin{tabular}{|c|c|c|c|c|c|c|}
\hline $\begin{array}{c}\text { Bağımlı } \\
\text { Değişken }\end{array}$ & Y1llık Gelir (i) & Y1llık Gelir (j) & Fark & Ortalamanın Karesi & $\mathrm{F}$ & $\mathrm{P}$ \\
\hline \multirow{6}{*}{$\begin{array}{l}\text { Ekonomik } \\
\text { Motivasyon }\end{array}$} & 10.000- TL ve alt1 & $50.001 \mathrm{TL}$ ve üstü &, $73395^{-}$ & \multirow{6}{*}{$\begin{array}{c}\text { Gruplar arası: } 2,593 \\
\text { Grup içi: } 0,831\end{array}$} & \multirow{6}{*}{3,77} & \multirow{6}{*}{0,001} \\
\hline & $10.001-20.000 \mathrm{TL}$ & $50.001 \mathrm{TL}$ ve üstü &, $74496^{-}$ & & & \\
\hline & \multirow{3}{*}{50.001 TL ve üstü } & 10.000- TL ve alt1 & ,73395* & & & \\
\hline & & $10.001-20.000 \mathrm{TL}$ & ,74496* & & & \\
\hline & & Gelirim yok & ,63592* & & & \\
\hline & Gelirim yok & $50.001 \mathrm{TL}$ ve üstü &, $63592^{*}$ & & & \\
\hline \multirow{8}{*}{$\begin{array}{l}\text { Çalışma } \\
\text { Motivasyonu }\end{array}$} & \multirow{2}{*}{ 10.000- TL ve altı } & 50.001 TL ve üstü &, $51500^{*}$ & \multirow{8}{*}{$\begin{array}{c}\text { Gruplar arası: } 2,593 \\
\text { Gruplar içi: } 0,831\end{array}$} & \multirow{8}{*}{5,070} & \multirow{8}{*}{0,000} \\
\hline & & Gelirim yok &, $33692^{*}$ & & & \\
\hline & $30001-40000 \mathrm{~T}$ & 50.001 TL ve üstü &, $59309^{*}$ & & & \\
\hline & & Gelirim yok &, $41500^{*}$ & & & \\
\hline & \multirow{2}{*}{50.001 TL ve üstü } & 10.000- TL ve alt1 &, $51500^{*}$ & & & \\
\hline & & $30.001-40.000 \mathrm{TL}$ &, $59309^{*}$ & & & \\
\hline & \multirow{2}{*}{ Gelirim yok } & 10.000- TL ve alt1 &, $33692^{*}$ & & & \\
\hline & & $30.001-40.000 \mathrm{TL}$ & ,41500* & & & \\
\hline
\end{tabular}

Varyansların homojen dağılmadığı motivasyon faktörleri için yapılan ANOVA (post hoc Games- Howell) analizinde, ekonomik motivasyonun daha az yıllık geliri olan gruplarda daha yüksek yıllık geliri olan gruplara göre daha yüksek olduğu görülmüştür. Buna göre yıllık geliri 20 bin TL'ye kadar olan gruplar para sıkıntısından kurtulmak, aile gelirine katkı sağlamak ve ailelerinin zenginleşmesini sağlamak ile borçlarını kapatacak parayı kazanma noktasında ekonomik bir motivasyona diğer gelir gruplarına kıyasla daha fazla sahiptir.

Çalışma motivasyonunda ise 10 bin TL ve altı geliri olanlar geliri olmayanlarla 50 bin TL ve üzerinde geliri olanlara; 30 bin TL ile 40 bin TL arasında geliri olanlar geliri olmayanlara ve 50 bin TL ve üzeri geliri olanlara; 50 bin TL geliri olanlar 10 bin TL ve altı geliri olanlar ve 30 bin TL ile 40 bin TL olanlara; geliri olmayanlar ise 10 bin TL ve alt ile 30 bin- 40 bin TL arasında geliri olanlara göre daha yüksek bir çalışma motivasyonuna sahiptir. Buna göre bu gruplar lider olma, işletmecilik tutkusu, doğuştan gelen yetenekleri ve uzmanlıklarını kullanma, işveren olma, işten tatmin olma, yeteneğe göre en iyi parasal karş1lığı alma noktasında daha yüksek bir motivasyona sahiptir. 
Beyhan Aksoy \& Mustafa Koçancı \& Mete Kaan Namal / Girişimcilik Motivasyonu: Uygulamalı Girişimcilik Eğitimi Katılımcıları Örneği

Tablo 7: Eğitim düzeyi ile girişimcilik motivasyonları arasındaki ilişkiler (Varyansları homojen dağılan motivasyonlar)

\begin{tabular}{|c|c|c|c|c|c|c|}
\hline $\begin{array}{c}\text { Bağımlı } \\
\text { Değişken }\end{array}$ & $\begin{array}{l}\text { Eğitim Düzeyi } \\
\text { (i) }\end{array}$ & $\begin{array}{c}\text { Eğitim Düzeyi } \\
\text { (j) }\end{array}$ & Fark & $\begin{array}{c}\text { Ortalamanın } \\
\text { Karesi } \\
\end{array}$ & $\mathrm{F}$ & $\mathrm{P}$ \\
\hline \multirow{12}{*}{$\begin{array}{l}\text { Toplumsal } \\
\text { Motivasyon }\end{array}$} & \multirow{2}{*}{ İlkokul } & Lisans &,$- 49264^{*}$ & \multirow{12}{*}{$\begin{array}{l}\text { Gruplar arasinda: } \\
5,269\end{array}$} & \multirow{12}{*}{6,494} & \multirow{12}{*}{0,000} \\
\hline & & Lisansüstü & $88290^{*}$ & & & \\
\hline & \multirow{2}{*}{ Ortaokul } & Lisans &,$- 41097^{*}$ & & & \\
\hline & & Lisansüstü &,$- 80123^{*}$ & & & \\
\hline & Lise & Lisans &,$- 37407^{*}$ & & & \\
\hline & \multirow{4}{*}{ Lisans } & Lisansüstü &,$- 76433^{*}$ & & & \\
\hline & & İlkokul & ,49264* & & & \\
\hline & & Ortaokul & , 41097* & & & \\
\hline & & Lise &, $37407^{*}$ & & & \\
\hline & \multirow{3}{*}{ Lisansüstü } & İlkokul & ,88290* & & & \\
\hline & & Ortaokul & $80123^{*}$ & & & \\
\hline & & Lise &, $76433^{*}$ & & & \\
\hline
\end{tabular}

Yapılan ANOVA (Post Hoc Tukey) testi sonuçlarına göre varyansların homojenliği çalışma motivasyonu, bireyci motivasyon ve toplumsal motivasyon başlıklarında sağlanmış olup, $p$ değeri $(p=0,000$ ve $p<0,05)$ bu imlerden sadece toplumsal motivasyon iminde girişimci adaylarının eğitimleri ile anlamlı bir farklı1ık sağlamıştır. Buna göre ilkokul, ortaokul ve lise mezunları, lisans ve lisansüstü mezunlarına göre anlamlı bir şekilde farklılık göstermiştir. Bir başka ifade ile daha düşük eğitim seviyesine sahip olan girişimci adayları başkalarıyla rekabet ederek kendilerini kanıtlamak, hiç kimseden bir eksikleri olmadığını göstermek, hayatın lükslerinin tadını çıkarmak, insanların saygısını kazanmak, yüksek statülere erişmek, büyük bir servete kavuşmak ve başkalarının yapamadığı işleri yapmak/ başarmak noktasında yüksek eğitim almış kişilere göre daha fazla motive olmuş durumdadır.

Tablo 8: Eğitim düzeyi ile girişimcilik motivasyonları arasındaki ilişkiler (Varyansları homojen dağılmayan motivasyonlar)

\begin{tabular}{|c|c|c|c|c|c|c|}
\hline $\begin{array}{c}\text { Bağımlı } \\
\text { Değișken }\end{array}$ & $\begin{array}{l}\text { Eğitim } \\
\text { Düzeyi (i) }\end{array}$ & $\begin{array}{c}\text { Eğitim } \\
\text { Düzeyi (j) }\end{array}$ & Fark & Ortalamanın Karesi & F & $P$ \\
\hline \multirow{5}{*}{$\begin{array}{l}\text { Ekonomik } \\
\text { motivasyon }\end{array}$} & \multirow{2}{*}{ Lise } & Önlisans &,$- 41590^{*}$ & \multirow{5}{*}{$\begin{array}{c}\text { Gruplar arası: } 3,155 \\
\text { Gruplar içi: } 0,853\end{array}$} & \multirow{5}{*}{3,701} & \multirow{5}{*}{0,003} \\
\hline & & Lisans &,$- 27215^{*}$ & & & \\
\hline & \multirow{2}{*}{ Önlisans } & Lise & $41590^{*}$ & & & \\
\hline & & Lisans & , 14375 & & & \\
\hline & Lisans & Lise & $27215^{*}$ & & & \\
\hline \multirow{4}{*}{$\begin{array}{l}\text { Girişimci } \\
\text { Motivasyon }\end{array}$} & Lise & Lisans &,$- 28272^{*}$ & \multirow{4}{*}{$\begin{array}{c}\text { Gruplar arasi: 1,960 } \\
\text { Gruplar içi: } 0,569\end{array}$} & \multirow{4}{*}{3,445} & \multirow{4}{*}{0,004} \\
\hline & Önlisans & Lisans &,$- 30096^{*}$ & & & \\
\hline & \multirow{2}{*}{ Lisans } & Lise & ,28272* & & & \\
\hline & & Önlisans & ,30096* & & & \\
\hline
\end{tabular}


Varyansların homojen dağılmadığı motivasyon faktörleri için yapılan ANOVA (post hoc Games- Howell) analizinde eğitim durumları farklılıklarının ekonomik ve girişimci motivasyonlar üzerinde anlamlı bir farklılık gösterdiği gözlemlenmiştir. Buna göre ekonomik kazanç motivasyonu lise mezunlarında önlisans ve lisans mezunlarına göre anlamlı bir farklılık göstermektedir. Bir başka ifadeyle lise mezunları, para sıkıntısından kurtulmak, aile gelirine katkıda bulunmak, ailenin zenginleşmesini sağlamak, çocuklarına parasal açıdan istikrar sağlamak ve borçlarını kapatacak parayı kazanmak noktasında diğer eğitim düzeylerine göre daha yüksek bir motivasyona sahiptir.

Benzer bir durum girişimci motivasyonu için de söylenebilir. Buna göre lise ve önlisans mezunlarının, lisans mezunlarına göre anlamlı bir girişimci motivasyon farklılı̆̆ı bulunmaktadır. Lise ve önlisans mezunları insanlara istihdam sağlama, topluma iyi mal veya hizmetler sunma, karar verme problem çözme becerilerini bir kariyer yaratmada kullanma, yaratıcı yenilikçi bir şeyler yapma, devletin ya da diğer kurumların sunduğu kredi veya desteklerden faydalanma, risk alma becerilerini kullanarak başarılı olma gibi konularda lisans mezunlarından anlamlı bir farkl1lik göstermektedir.

\section{SONUÇ VE ÖNERILER}

Girişimcilik, iş yaratma veya ekonomik büyüme sağladığı için teşvik edilse bile, bireyler girişimciliğe çoğu zaman kazanç elde etme gibi ekonomik ya da başarma gibi psikolojik faktörler bağlamında yöneltmektedirler. Çalışmamızda girişimcilik süreçlerine dair daha ayrıntılı bir anlayış geliştirmek üzere kişileri girişimciliğe yönelten motivasyonları anlamak ve açıklamak araştırmamızın temel sorunsalı olarak belirlenmiştir. Araştırma sonuçlarının girişimcilik alanına ve uygulamalı girişimcilik eğitimlerine katkı sunması hedeflenmiştir.

Girişimcilik eğitim programlarına kamu kaynaklarından aktarılan işgücü, zaman ve finansman, eğitim programlarının veri temelli ve akılcı bir şekilde tasarlanmasını gerektirmektedir. $\mathrm{Bu}$ anlamda girişimci adaylarının motivasyonlarını değerlendirmek program içeriklerini ve kapsamını düzenleme açısından faydalı olabilir.

Gelir düzeyi, ihtiyaç ve firsat girişimciliğini ayırt etme potansiyeli bakımından araştırmamız için önemli bir değişken olarak tanımlanmıştır. Araştırmamızda bir geliri olmayan katılımcıların oranı \% 36,7 iken, asgari ücret standartlarının altında geliri olan kesim \%31'lik bir orana sahiptir. Yani katılımcıların üçte ikisinin ihtiyaç girişimciliği kapsamında değerlendirilmesi mümkündür.

Araştırmada kullandığımız motivasyon ölçeğinden elde ettiğimiz verilerle ortaya çıkan temel faktörler; ekonomik odak, girişimcilik odağı, toplumsal odak, çalışma odağı ve bireycilik odakları başlıklarında tanımlanmıştır. Araştırma sonuçlarına göre girişimcilik motivasyonunun toplumsal yönü ve çalışma yönü erkeklerde daha yüksek düzeyde bulunmuştur. $\mathrm{Bu}$ sonuç erkeklerin kendini kanıtlama potansiyelini kullanma ve kendini gerçekleştirme bakımından girişimciliği bir kariyer olarak benimsediklerini ve çalışma anlayışlarının da bu bağlamda biçimlendiğini işaret etmektedir. Öte yandan daha önceki girişimcilik 
tecrübeleri, kişilerin kendileri ile ilgili (bireyci) beklentilerini artıran bir etki yaratmaktadır. Ücretli çalışmanın bazı avantajlarına rağmen kişiler bağımsız ve kendi tercihi olan bir iş yapmayı istemektedirler. Bu sonuç, girişimciliği bireylerin değişimi yönetmenin bir yolu olarak gördükleri şeklinde yorumlanabilir.

İhtiyaç - firsat girişimciliği sınıflamasını daha iyi anlamamızı sağlayan gelir değişkeniyle ilgili sonuçlar göstermektedir ki, yüksek gelir düzeyine sahip olan kişiler toplumsal statülerini daha fazla yükseltecek bir arayış içindedirler. Yine aynı grup için motivasyonun bireyci yönü de ağır basmaktadır. Düşük gelir grubundaki ihtiyaç girişimcileri ise tahmin edilebileceği gibi daha çok ekonomik bir motivasyona sahiptirler. Gelir ve ekonomik motivasyon ilişkisinde ise lise mezunlarının daha yüksek bir motivasyona sahip olduğu görülmektedir.

Eğitim düzeyi açısından bakıldığında, lise ve altı eğitime sahip kesimin daha üst eğitim almış kesime göre toplumsal motivasyonu daha yüksek bulunmuştur. Yani bu kimselerin toplumsal statü ve kendini kanıtlama gibi isteklere daha fazla sahip olduğu söylenebilir. Daha üst eğitim seviyelerine kavuşamayan bu kesim, eğitimle elde etmeleri olası ancak elde edemedikleri bir statüyü girişimcilik başarısı ile kazanmayı bekliyor olabilirler. Bunun dışında bir işe girip çalıştıklarında, eğitimli kimseler kadar yükselme imkânına sahip olamayacakları düşüncesiyle, girişimci olarak (eğitimli ya da değil) diğerlerini istihdam ederek onları yönetme imkânına kavuşmak da kişileri motive edebilir.

Çalışmamızda bazı değişkenler temelinde motivasyonun nasıl farklılaşabileceğini yorumlamayı hedefledik. Bununla birlikte bu süreçlerin aktörlerin yaşam tecrübeleri içerisinde nasıl gerçekleştiğini daha ayrıntılı anlayabilmek için bu konu özelinde nitel araştırmalar yapılmasına ihtiyaç vardır.

Araştırmamızın sınırlılıklarından biri, girişimci adaylarının kendilerini ve girişimcilik potansiyellerini nasıl gördüklerine dair bir değerlendirme yapılmamış olmasıdır. Yani katılımcıların gelecekte kendilerini bir girişimci olarak ne ölçüde gördükleri sorusu araştırmamıza dahil edilmemiştir. Kişilerin öz yeterlik inancı ile yakından ilişkili olan bu olgunun ayrıca sorgulanmasına ihtiyaç vardır. Girişimcilik eğitimini kendi kişisel gelişimi için bir artı olarak gören ya da girişimciliği alternatif bir kariyer yolu olarak tanımlayan kesimlerle, mutlaka bir iş kurarak hayatını sürdüreceklerini düşünen ve kendi girişimcilik potansiyeline tamamen inanan grupların ayrıştırılması faydalı olacaktır. Bu önerideki temel varsayım, kendi öz yeterliklerine inanan kesimlerin bu süreçte elde edebilecekleri girişimcilik başarılarının farklılaşacağı ile ilişkilidir. Dolayısıyla bundan sonraki araştırmalarda girişimcilik hevesinin seviyesini ya da kişinin sürece olan bağlılı̆ğı ve inancını ölçen değişkenler araştırmaya dahil edilerek farklı motivasyon türlerinin bu bakımdan incelenmesi faydalı olabilir.

KAYNAKÇA

Ajzen, I. (1991). "The theory of planned behavior" Organizational behavior and human decision processes, 50(2), 179-211.

Amit, R., \& Muller, E. (1995). "Push and pull entrepreneurship", Journal of Small Business \& Entrepreneurship, 12(4), 64-80. 
Aramand,M. (2012) "Women entrepreneurship in Mongolia: the role of culture on entrepreneurial motivation”, Equality, Diversity and Inclusion: An International Journal, Vol. 32 Issue: 1, pp.68-82,

Bandura, A. (1994). Self-efficacy. In V. S. Ramachaudran (Ed.), Encyclopedia of human behavior (Vol. 4, pp. 71-81). New York: Academic Press.

Bourlès, R., ve Cozarenco, A. (2017). "Entrepreneurial motivation and business performance: evidence from a French microfinance institution", Small Business Economics, 1-21.

Burton, M. D., Sørensen, J. B., ve Dobrev, S. D. (2016). "A careers perspective on entrepreneurship", Entrepreneurship Theory and Practice, 40(2), 237-247.

Carsrud, A., ve Brännback, M. (2011). "Entrepreneurial motivations: what do we still need to know? ", Journal of Small Business Management, 49(1), 9-26.

Collins, C., Hanges, P. and Locke, E.A. (2004), "The relationship of achievement motivation to entrepreneurial behavior: a meta-analysis", Human Performance, Vol. 17 No. 1, pp. 95-117.

Davidsson, P. ve Delmar, F. (1992). "Cultural Values and Entrepreneurship", Frontiers of Entrepreneurial Research. Wellesley, Massachusetts: Babson College, pp. 444-458.

Douglas, E.J. and Shepherd, D.A. (1999), "Entrepreneurship as a utility maximizing response", Journal of Business Venturing, Vol. 15 No. 3, pp. 231-51.

Polat, D. D. (2011). "Girişimcilik Motivasyonu ve İşletme Yenilikçiliği Arasındaki İlişkinin Araştırılmasına Yönelik Turizm İşletmelerinde Bir Araştırma", Girişimcilik ve Kalkınma Dergisi, 6(2), 227-254.

Dubini, P. (1989). "The influence of motivations and environment on business start-ups: Some hints for public policies", Journal of business venturing, 4(1), 11-26.

Fayolle, A., Liñán, F., ve Moriano, J. A. (2014). "Beyond entrepreneurial intentions: values and motivations in entrepreneurship", International Entrepreneurship and Management Journal, 10(4), 679-689.

Gatewood, E. J., K. G. Shaver and W. B. Gartner, 1995, “A Longitudinal Study of Cognitive Factors Influenc- ing Start-up Behaviours and Success at Venture Creation”, Journal of Business Venturing 10, 371-391.

GEM (2018) Global Entrepreneurship Research Association (GERA) Global Entrepreneurship Monitor 2017-2018 Global Report https://www.gemconsortium.org/ report/50012

Hessels, J., Van Gelderen, M., ve Thurik, R. (2008). "Entrepreneurial aspirations, motivations, and their drivers", Small Business Economics, 31(3), 323-339.

Johnson, B.R. (1990), "Toward a multidimensional model of entrepreneurship: the case of achievement motivation and the entrepreneur", Entrepreneurship Theory and Practice, Vol. 14 No. 3, pp. 39-54.

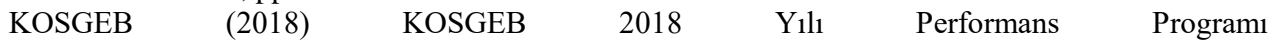
https://www.kosgeb.gov.tr/Content/Upload/Dosya/Mali\%20Tablolar/Performans\%20Prog ram\%C4\%B1/KOSGEB_2018_Y\%C4\%B11\%C4\%B1_Performans_Program\%C4\%B1.pd f, Erişim Tarihi:1.2.2019.

Marques, C. S., Ferreira, J. J., Ferreira, F. A., ve Lages, M. F. (2013). "Entrepreneurial orientation and motivation to start up a business: evidence from the health service industry", International Entrepreneurship and Management Journal, 9(1), 77-94.

McClelland, D. C. (1967). The achieving society. New York, NY, US: Free Press.

Minola, T., Criaco, G., ve Obschonka, M. (2016). "Age, culture, and self-employment motivation", Small Business Economics, 46(2), 187-213.

Namal, M. K., Koçancı, M., ve Aksoy, B. (2018). "KOSGEB Girişimcilik Programı: Eleştirel Bir Değerlendirme", Akademik Hassasiyetler, 5(9), 93-110.

Nunnally, J. C. (1978). Psychometric Theory. Mc Graw- Hill 2. Bask1, New York.

Okangi, F. F. (2018). "Linking Entrepreneurial Motivation Factors To Firm Growth: Empirical Evidence From The Construction Industry In Tanzania", Business Management Review, 21(2), 30-42.

Özdemir, A. A. (2010). "Potansiyel Girişimci Olan Kadınların Motivasyon Faktörleri ve Eskişehir'de Bir Araştırma", Ege Akademik Bakis, 10(1), 117. 
Rusu, V. D. (2018). "Entrepreneurial motivations in the European Union countries", Management Dynamics in the Knowledge Economy, Vol.6 (2018) no.1, pp.9-31

Shane, S., Locke, E. A., ve Collins, C. J. (2012). "Entrepreneurial motivation", Human Resource Management Review, 13(2), 257-279.

Shane, S., ve Venkataraman, S. (2000). "The promise of entrepreneurship as a field of research", Academy of Management Review, 25(1), 217-226.

Stephan, U., Hart, M., ve Drews, C. (2015). Understanding motivations for entrepreneurship: A review of recent research evidence. Birmingham: Enterprise Research Center, University of Sheffield.

Tekin, M. (1999). Girişimcilik: Kendi İşini Kurma ve İşletme, Damla Ofset, Konya.

Van Gelderen, M., Thurik, R., ve Bosma, N. (2005). "Success and risk factors in the pre-startup phase", Small business economics, 24(4), 365-380.

Venkataraman, S. (1997). "The distinctive domain of entrepreneurship research", Advances in entrepreneurship, firm emergence and growth, 3(1), 119-138.

Vidic, F., Yeşil, Y., Çalış, A.S., Arpat, B. (2016). "Analyzing and Comparing the Properties of Women Entrepreneurship in Slovenia and Turkey”, Akademik Sosyal Araştırmalar Dergisi, $4(32), 352-371$.

Vijaya, V., ve Kamalanabhan, T. J. (1998). "A scale to assess entrepreneurial motivation", The Journal of Entrepreneurship, 7(2), 183-198.

Yalçın, S. ve Kapu, H. (2008). "Entrepreneurial dimensions in transitional economies: A review of relevant literature and the case of Kyrgyzstan", Journal of Developmental Entrepreneurship, 13(2), 185-203.

Zimmerman, M. A., ve Chu, H. M. (2013). "Motivation, success, and problems of entrepreneurs in Venezuela", Journal of Management Policy and Practice, 14(2), 76-90

\section{SUMMARY}

Entrepreneurship motivation is a force that is effective on entrepreneurship processes as it sets people into motion towards goals. Therefore, understanding and explaining the motivations that lead people to entrepreneurship is defined as the main problem of the research.

Most of the economic approaches to entrepreneurship processes show that entrepreneurial motivation is based on the difference in expected benefits between starting a business and paid work. On the other hand, individual and psychological characteristics such as autonomy, creativity, gender, innovation, focus of control, need for success, organization and leadership skills, risk taking, self-confidence and self-esteem can be determinative on motivation. The costs created by the negative consequences such as not every desire or enthusiasm becoming an entrepreneurship, failure or abandonment make motivation factors an important research topic. For this reason, we aimed to develop an understanding of the subject and to present some suggestions based on the data obtained from the field research that we made to explain the entrepreneurial motivations of entrepreneur candidates who have intention to start a business by participating in KOSGEB entrepreneurship trainings.

Starting from this, 589 entrepreneur candidates who participated in KOSGEB Applied Entrepreneurship Training in Antalya Province in August September - October 2016 were interviewed face to face and entrepreneurial motivations of entrepreneur candidates were explained in the study. How the 
entrepreneurial motivation changed in terms of some selected demographic variables was revealed by descriptive statistics, $t$ tests, ANOVA and factor analysis.

The entrepreneurial motivation scale developed by Vijaya and Kamalanabhan (1998) consists of the main factors entrepreneurial core, working core, social core, individualism core and economic core. Although similar factors emerged in this study, some variables were gathered in different factors due to reasons from cultural differentiation.

According to the research findings, it is found that men have higher motivation than women in terms of social and work attitudes. Those who have experience in entrepreneurship have more individualistic motivation than those without entrepreneurship experience. Those whose income level is over 50 thousand TL annually are more motivated in social motivation dimension. Entrepreneurial candidates who have higher income levels also have higher level of individualistic motivation than other income groups and non-income groups. Groups with an annual income of up to 20 thousand TL have more economicalbased motivation compared to other income groups. Entrepreneur candidates with lower levels of education have been found to be more motivated than those who are highly educated in both entrepreneurial and economic motivation dimensions. 